\title{
The Relative Tolerance of Six Prunus Rootstocks to Boron and Salinity
}

\author{
Rawia El-Motaium, Hening Hu, and Patrick H. Brown ${ }^{1}$ \\ Department of Pomology, University of California, Davis, CA 95616 \\ Additional index words. almond, peach, plum, regression analysis
}

\begin{abstract}
The influence of $\mathrm{B}$ and salinity $\left[3 \mathrm{Na}_{2} \mathrm{SO}_{4}: 1 \mathrm{CaCl}_{2}\right.$, (molar ratio) $]$ on $\mathrm{B}$ toxicity and the accumulation of $\mathrm{B}$, sodium, and $\mathrm{SO}_{4}$ in six Prunus rootstocks was evaluated. High salinity reduced B uptake, stem B concentrations, and the severity of toxicity symptoms in five of the six rootstocks. Forward and backward stepwise regression analyses suggested that stem death (the major symptom observed) was related solely to the accumulation of $B$ in the stem tissue in all rootstocks. The accumulation of $B$ and the expression of toxicity symptoms increased with time and affected rootstock survival. No symptoms of $B$ toxicity were observed in leaf tissue. The Prunus rootstocks studied differed greatly in stem $B$ accumulation and sensitivity to $B$. The plum rootstock 'Myrobalan' and the peach-almond hybrid 'Bright's Hybrid' were the most tolerant of high $B$ and salinity, whereas the peach rootstock 'Nemared' was very sensitive to high B and salinity. In all rootstocks, adding $\mathrm{B}$ to the growth medium greatly depressed stem $\mathrm{SO}_{4}$ concentrations. In every rootstock except 'Nemared' peach, adding salt significantly depressed tissue $B$ concentrations. A strong negative correlation between tissue $\mathrm{SO}_{4}$ and B was observed. Grafting experiments, in which almond was grafted onto 'Nemared' peach or 'Bright's Hybrid', demonstrated the ability of rootstocks to influence $B$ accumulation and scion survival.
\end{abstract}

Boron is an essential micronutrient that is often found in high concentrations in association with saline soils and saline well water (Dhankhar and Dahiya, 1980). Although B toxicity is closely associated with salinity problems (Nicholaichuk et al., 1988), it is not known whether B and salinity interact to impair the growth of fruit tree species.

Stone fruit trees are classified as relatively sensitive to salinity (Greenway and Munns, 1980; Maas, 1986). Hoffman et al. (1988) and Catlin et al. (1993) have demonstrated that growth of 'Santa Rosa' plum on 'Myrobalan' rootstock was not significantly reduced by exposure to soil conductivities of 4 and $8 \mathrm{dS} \cdot \mathrm{m}^{-1}$ for one season, but continued exposure to these salinity levels resulted in yield declines in the second season. Catlin et al. (1993) calculated that 3 years of growth of 'Santa Rosa' plum in soils with an electrical conductivity $>2.5 \mathrm{dS} \cdot \mathrm{m}^{-1}$ would reduce production measurably. Excess B and salinity are significant problems in California, where $>150,000$ ha in the San Joaquin Valley have been impacted by salinity (Croughan and Rains, 1982). This region produces more than $\$ 1$ billion a year in almonds and stone fruit.

Published studies on the accumulation of toxic ions and the development of symptomology in plant species exposed to a combination of high B and salinity are limited. Eaton (1944) described a range of symptoms associated with B toxicity and emphasized that species differ greatly in their response to excess B. In Prunus, B toxicity has been associated with stem dieback, gum formation, and cracking and splitting of the bark (Woodbridge, 1955). Leaf symptoms of B toxicity have not been described for Prunus, and, as a result, the recognition of B toxicity in the field is severely inhibited.

Rootstock can greatly affect the scion's tolerance to salinity (Bernstein et al., 1956; Hayward et al., 1946) or high B concentration (Hansen, 1948, 1955). For example, almond and peach scions grafted onto 'Marianna' plum rootstock consistently had lower $\mathrm{Cl}$ accumulation and less growth inhibition than those grafted onto

Received for publication 20 Dec. 1993. Accepted for publication 16 May 1994. We acknowledge the support of the Univ. of California Salinity Drainage Task Force and the Almond Board of California. We are grateful to Douglas V. Shaw for advice in statistical analysis. The cost of publishing this paper was defrayed in part by the payment of page charges. Under postal regulations, this paper therefore must be hereby marked advertisement solely to indicate this fact.
'Lovell' peach (Bernstein et al., 1956). In a comparison of rootstock effects on B tolerance, Hansen $(1948,1955)$ observed that French prune on 'Marianna' plum or peach roots showed more stem injury than those on almond or 'Myrobalan' plum rootstocks. None of these studies, however, considered interactions between $\mathrm{B}$, salinity, and rootstock, and few have adequately discussed the accumulation of ions in plant tissues and its association with tree performance (Bernstein et al., 1956). Furthermore, information is required on the response of fruit trees to a combination of $\mathrm{Na}_{2} \mathrm{SO}_{4}$, $\mathrm{CaCl}_{2}$, and $\mathrm{B}$ typical of many areas of the western San Joaquin Valley of California and many similar areas in the world.

The objectives of this study were to 1 ) investigate the interactions of $\mathrm{Na}_{2} \mathrm{SO}_{4}$ and $\mathrm{CaCl}_{2}$ salinity and $\mathrm{B}$ supply on the accumulation of $\mathrm{B}, \mathrm{Na}$, and $\mathrm{SO}_{4}$ in various plant parts, 2) study the relationship between the concentration of these ions, plant growth, and the expression of toxicity symptoms in six rootstocks, and 3) determine if rootstock can influence scion tolerance to excessive B or salinity stresses in the root environment.

\section{Materials and Methods}

Six commercial Prunus rootstocks-'Lovell', 'Nemaguard' and 'Nemared' peach (Prunus persica Batsch), 'Marianna 2624' and 'Myrobalan' plum (P. salicina Lindl), and 'Bright's Hybrid' (almond-peach hybrid) [P. amygdalus Batsch syn. P. dulcis (Mill.) D.A. Webb 'Mission' $x$ P. persica 'Nemared']-were used in this experiment. 'Marianna 2624' cuttings and seeds of 'Myrobalan', 'Nemaguard', and 'Nemared' were obtained from the U.S. Dept. of Agriculture Germplasm Repository, Davis, Calif. 'Marianna 2624' cuttings were rooted in Fall 1990 and 'Myrobalan', 'Nemaguard' and 'Nemared' seeds were planted in April 1991 after 2 months of chilling at 5C. 'Lovell' and 'Bright's Hybrid' seedlings were obtained in April and May 1991 from Bright's nursery near LeGrand, Calif. All rootstocks were transplanted into pots in May 1991 and grown at a field site near Davis. Plants were grown in 11-liter pots filled with perlite. Each pot contained two plants. Boron $\left(\mathrm{H}_{3} \mathrm{BO}_{3}\right)$ was supplied at $0.025,0.5$, and $1.0 \mathrm{~mm}$ and salinity was provided as $3 \mathrm{Na}_{2} \mathrm{SO}_{4}: 1 \mathrm{CaCl}_{2}$ (molar ratio) to the growth medium to a final electrical conductivity of 2,6 , or 12 $\mathrm{dS} \cdot \mathrm{m}^{-1}$. The experiment was a three $(\mathrm{B}) \times$ three (salinity) $\times$ six 
(rootstocks) factorial, repeated in six replications, with 108 trees per replicate. A total of 324 pots (648 trees) was used. During the experiment, plants were irrigated to field capacity with deionized water as necessary. Care was taken to avoid through-flow of water.

In the pretreatment period from 1 May to 24 June, plants were fertilized twice each week with half-strength Hoagland solution (Hoagland and Arnon, 1950). Beginning 24 June, all plants were fertilized with full-strength Hoagland solution twice each week, with additional irrigation to field capacity as necessary. On 26 July, when all plants were growing vigorously and uniformly, B and salinity treatments were initiated by adding the treatment solution with the nutrient solution. After 3 months of treatment in the first season, treatments and nutrient applications were halted during the dormant period (November to February). All plants were transplanted from 11- to 15-liter pots before the second growing season (February 1992), and the treatments were reinitiated in March 1992.

In May 1991, an additional experiment was initiated using 'Titan' almond grafted to either 'Bright's Hybrid' or 'Nemared' rootstock. The plants consisted of 1-year-old scions on 2-year-old rootstocks. They were arranged, one plant per pot, into the following four treatment combinations: a) $0.025 \mathrm{~mm} \mathrm{B,} 2 \mathrm{dS} \cdot \mathrm{m}^{-1}$ salt, b) $1.0 \mathrm{~mm} \mathrm{~B}, 2 \mathrm{dS} \cdot \mathrm{m}^{-1}$ salt, c) $0.025 \mathrm{~mm} \mathrm{~B}, 12 \mathrm{dS} \cdot \mathrm{m}^{-1} \mathrm{salt}$, and d) 1.0 $\mathrm{mm} \mathrm{B}, 12 \mathrm{dS} \cdot \mathrm{m}^{-1}$ salt. Each treatment combination was replicated four times. Nutrient solutions, treatment applications, and water were applied as described above.

In all treatments, toxicity symptoms and growth were recorded, and leaf samples from midshoot of the current season's growth were collected in late August and November 1991 (1 and 4 months

Table 1. General linear models procedure analysis of percentage stem death after arcsin transformation. Stem death was determined 14 months after exposing six Prunus rootstocks to varying B and salinity treatments.

\begin{tabular}{lrcc}
\hline \hline Source & df & Mean square & F value \\
\hline B & 2 & 40,000 & $257^{* *}$ \\
Salinity (S) & 2 & 933 & $6.01^{* * *}$ \\
Rootstock (R) & 5 & 10,900 & $70.4^{* *}$ \\
$\mathrm{~B} \times \mathrm{S}$ & 4 & 1,460 & $9.41^{* * *}$ \\
$\mathrm{~B} \times \mathrm{R}$ & 10 & 2,370 & $15.3^{* *}$ \\
$\mathrm{~S} \times \mathrm{R}$ & 10 & 430 & $2.77^{* *}$ \\
$\mathrm{~B} \times \mathrm{S} \times \mathrm{R}$ & 20 & 405 & $2.61^{* *}$ \\
Error & 258 & 155 & \\
\hline
\end{tabular}

${ }^{* * *}$ Significant at $P<0.01$. of treatment, respectively) and again in September 1992 (14 months of treatment). Stems ( $<4 \mathrm{~mm}$ in diameter) and roots $(<2$ $\mathrm{mm}$ in diameter) were collected in February and September 1992. Boron toxicity in the shoots was estimated as percentage length of dead shoots vs. total shoot length. The total dry weight for each pot was determined at the end of the experiment.

All samples were oven-dried at $70 \mathrm{C}$ to a constant weight, weighed, ground to pass a 30 -mesh screen, and ashed at $500 \mathrm{C}$ for $16 \mathrm{~h}$. After ashing, samples were digested in $1 \%$ nitric acid, and ion concentration was determined by inductively coupled plasma spectroscopy (Thermo Jarell Ash Corp., Menlo Park, Mass.). Sulfate-S was extracted and analyzed according to Littlefield et al. (1990). Chloride was determined by a chloridometer (Haake Buchler, Saddle Brook, N.J.).

Statistical analysis. Statistical analysis was performed using SAS's general linear models and stepwise procedures (SAS Institute, 1982). Percentage data were arcsin-transformed (Fernandez, 1992; Gomez and Gomez, 1984). Stem B concentration was logtransformed, and dry weight was cubic-root-transformed according to the criteria outlined by Fernandez (1992). Forward and backward stepwise regression was performed using nontransformed stem death as the dependent variable and $\mathrm{B}, \mathrm{Na}$, and $\mathrm{SO}_{4}-\mathrm{S}$ in the leaf and stem as independent factors. Analysis of treatment effects indicated that stem death, dry weight, and stem B concentration were affected by two- and three-way interactions between B, salinity, and rootstock. Statistical comparisons of main effect are therefore not valid. Results for the first and second year of the experiment were similar. Only second year results are presented here.

\section{Results}

Plant growth and symptoms. Toxicity symptoms were observed 4 months after treatment and persisted into the second year of the experiment. The most significant toxicity symptom occurred in the stem and included shoot die back, gummy exudates, or necrotic spots along the lower or middle part of a stem and finally whole shoot death. This toxicity symptom was caused solely by B, as no symptoms were observed with salinity treatments alone. There were no apparent leaf symptoms in any treatments.

Stem death was affected by a three-way interaction $(P<0.01)$ between B, salinity, and rootstock (Table 1). The results indicate that, under low salt ( $\left.2 \mathrm{dS} \cdot \mathrm{m}^{-1}\right)$, 'Marianna', and 'Lovell' were least tolerant of high B (1 mM) (98 and 91 stem death, respectively) (Table 2), while 'Myrobalan' was very resistant to high B (13\%

Table 2. Mean percentage stem death of six Prunus rootstocks grown under varying B and salinity treatments. Plants were exposed to treatments for 14 months.

\begin{tabular}{lcccccc}
\hline \hline B (mM)/ & \multicolumn{5}{c}{ Rootstock $^{\mathrm{z}}$} \\
\cline { 2 - 7 } salt $\left(\mathrm{dS} \cdot \mathrm{m}^{-1}\right)$ & $\mathrm{HY}$ & $\mathrm{LO}$ & $\mathrm{M}$ & $\mathrm{MA}$ & $\mathrm{NG}$ & NR \\
\hline $0.025 / 2$ & $3 \pm 1^{\mathrm{y}}$ & $18 \pm 1$ & $2 \pm 1^{\mathrm{y}}$ & $16 \pm 6$ & $5 \pm 1$ & $16 \pm 3$ \\
$0.5 / 2$ & $7 \pm 2$ & $40 \pm 8$ & $15 \pm 8^{\mathrm{y}}$ & $42 \pm 7$ & $33 \pm 7$ & $52 \pm 5$ \\
$1 / 2$ & $71 \pm 4$ & $91 \pm 8$ & $13 \pm 3$ & $98 \pm 1$ & $62 \pm 7$ & $78 \pm 13$ \\
$0.025 / 6$ & $2 \pm 1^{\mathrm{y}}$ & $17 \pm 3$ & $3 \pm 1^{\mathrm{y}}$ & $28 \pm 7^{\mathrm{y}}$ & $14 \pm 2$ & $12 \pm 6^{\mathrm{y}}$ \\
$0.5 / 6$ & $7 \pm 3$ & $35 \pm 2$ & $3 \pm 2^{\mathrm{y}}$ & $24 \pm 11$ & $21 \pm 1$ & $24 \pm 3$ \\
$1 / 6$ & $43 \pm 11$ & $56 \pm 8$ & $5 \pm 2$ & $100 \pm 0$ & $52 \pm 11$ & $99 \pm 0$ \\
$0.025 / 12$ & $2 \pm 1$ & $13 \pm 2$ & $6 \pm 1^{\mathrm{y}}$ & $14 \pm 8$ & $33 \pm 9$ & $30 \pm 7$ \\
$0.5 / 12$ & $4 \pm 2$ & $17 \pm 1$ & $4 \pm 3$ & $19 \pm 2$ & $24 \pm 3$ & $25 \pm 3$ \\
$1 / 12$ & $12 \pm 1$ & $66 \pm 19$ & $3 \pm 1$ & $63 \pm 5$ & $40 \pm 15$ & $100 \pm 0$
\end{tabular}

${ }^{\mathrm{z}} \mathrm{HY}=$ 'Bright's Hybrid', LO = 'Lovell', M = 'Myrobalan', MA = 'Marianna', NG = 'Nemaguard', NR = 'Nemared'. Values are untransformed original means $\pm \mathrm{SE}$.

yOnly four to five observations, all others had six observations. 
stem death only). At the intermediate salt concentration (6 $\left.\mathrm{dS} \cdot \mathrm{m}^{-1}\right)$, the relative sensitivities of the six rootstocks differed slightly from sensitivities at the low salt concentration. Thus 'Marianna' and 'Nemared' were most sensitive, 'Myrobalan' was least sensitive, and 'Lovell', 'Nemaguard', and 'Bright's Hybrid' were intermediate in their response. At the highest B level (1 mM), increasing salinity ( 2 to $12 \mathrm{dS} \cdot \mathrm{m}^{-1}$ ) decreased shoot death by $80 \%$, $30 \%, 70 \%, 30 \%$, and $30 \%$ in 'Bright's Hybrid', Lovell', 'Myrobalan', 'Marianna', and 'Nemaguard', respectively (Table 2). Only in 'Nemared' did increasing salinity increase shoot death percentages $(78 \%$ to $100 \%)$. A similar trend was apparent at intermediate B levels with increasing salinity. Thus, increasing salinity reduced B toxicity in all species except 'Nemared'. The rootstocks 'Marianna', 'Lovell', 'Nemaguard', and 'Nemared' were the most sensitive to high B and high salinity, while 'Myrobalan' and 'Bright's Hybrid' were least sensitive. 'Bright's Hybrid' is relatively tolerant of B, particularly if salinity is high, while 'Myrobalan' is tolerant of B at all salt levels used here.

Dry weight accumulation also depended on a three-way interaction between $\mathrm{B}$, rootstock, and salt $(P<0.05)$ (Table 3$)$. Under low salt, adding high $B$ greatly decreased dry weight accumulation in all species except 'Myrobalan' (Table 4). Under the highest B concentration, increasing salt level increased dry weight accumulation in 'Bright's Hybrid'. Thus, increasing salt mitigated the effects of B on 'Bright's Hybrid'. Intermediate salt levels also partially mitigated the effects of B in 'Marianna' and 'Myrobalan'. Under high B and high salt, 'Myrobalan' and 'Bright Hybrid' maintained $60 \%$ to $80 \%$ of control growth (low B and low salt) compared to $20 \%$ to $30 \%$ growth in the other rootstocks.

Table 3. General linear models procedure analysis of dry weight after cubic-root transformation. Dry weight was determined 14 months after exposing six Prunus rootstocks to varying B and salinity treatments.

\begin{tabular}{lrcc}
\hline \hline Source & df & Mean square & F value \\
\hline B & 2 & 32.7 & $146^{* *}$ \\
Salinity (S) & 2 & 2.39 & $10.6^{* *}$ \\
Rootstock (R) & 5 & 25.3 & $112^{* *}$ \\
$\mathrm{~B} \times \mathrm{S}$ & 4 & 2.13 & $9.47^{* * *}$ \\
$\mathrm{~B} \times \mathrm{R}$ & 10 & 1.04 & $4.66^{* *}$ \\
$\mathrm{~S} \times \mathrm{R}$ & 10 & 0.53 & $2.36^{*}$ \\
$\mathrm{~B} \times \mathrm{S} \times \mathrm{R}$ & 20 & 0.517 & $2.29^{* * *}$ \\
Error & 244 & 0.224 & \\
\hline
\end{tabular}

${ }^{* * * *}$ Significant at $P<0.05$ and 0.01 , respectively.
Correlation of stem death with elemental concentrations. A stepwise regression analysis (SAS Institute, 1982) was used to determine which independent variable $-\mathrm{B}, \mathrm{Na}$, or $\mathrm{SO}_{4}$ - in the leaf and stem was most likely to contribute to stem death (Table 5). Chloride data are not shown because $\mathrm{Cl}^{-}$did not accumulate to significant levels in any treatment $\left(\mathrm{Cl}^{-}\right.$concentrations in leaves ranged from 150 to $600 \mu \mathrm{g} \cdot \mathrm{g}^{-1}$ and were not significantly affected by treatment or rootstock effects). Stem B was the only variable that was significantly correlated with stem death. Further analysis of individual rootstocks and elemental concentrations suggests that there was no interactive effect between $\mathrm{Na}$ and $\mathrm{SO}_{4}$ in leaf tissue and the sensitivity of a plant to B toxicity. Thus, B accumulation in the stem tissue is the sole determinant of B toxicity. Any apparent effect of salinity on stem death may be attributed to the effect of salinity on stem B concentrations.

As with stem death and dry weight accumulation, B accumulation in the stem depended on a three-way interaction between $\mathrm{B}$, salinity, and rootstock $(P<0.01)$ (Tables 6 and 7$)$. The relationship between treatment, stem $\mathrm{B}$ concentration, and stem death can be easily recognized by comparing Tables 2 and 7. The B concentrations in stems of the various rootstocks varied with treatment and correlated well with stem death (Table 5). Thus, under high salinity, rootstocks with the highest stem B concentrations ('Nemared', 'Lovell') typically had the highest percentage of stem death, while 'Myrobalan' and 'Bright's Hybrid' had lower stem death and lower stem B concentrations (Tables 2 and 7). When B was supplied at its highest concentration, increasing salt level markedly decreased stem death at all species except 'Nemared' (Table 2). This decrease in stem death coincided with a salinityinduced decrease in stem B concentration (Table 2 vs. 7). During the experiment, the plum rootstock 'Myrobalan' exhibited remarkable tolerance to B and salinity (Table 2), which corresponded to the restricted accumulation of B in its stem (Table 7).

The relationship between stem $B$ concentrations and stem death was also apparent in experiments with grafted plants. The effect of rootstock ('Bright's Hybrid' and 'Nemared') on stem death and stem B accumulation is illustrated in Fig. 1. Plants grafted onto 'Bright's Hybrid' rootstock suffered considerably less stem death under low salinity and high B and high salinity and high B than those grafted to 'Nemared'. This difference was most marked at the highest salinity and B combination (Fig. 1, top). Here again, increasing salinity decreased the toxic effects of B when 'Bright's Hybrid' was used as the rootstock. The difference of stem death was due largely to the difference in B concentration in stem tissue of the scion that was as much as $75 \%$ less in plants grafted on

Table 4. Total dry weight [roots, leaves, and stems (g/pot)] of six Prunus rootstocks grown under varying B and salinity treatments. Plants were exposed to treatments for 14 months.

\begin{tabular}{|c|c|c|c|c|c|c|}
\hline \multirow{2}{*}{$\begin{array}{l}\mathrm{B}(\mathrm{mM}) / \\
\text { salt }\left(\mathrm{dS} \cdot \mathrm{m}^{-1}\right)\end{array}$} & \multicolumn{6}{|c|}{ Rootstock $^{\mathrm{Z}}$} \\
\hline & HY & LO & M & MA & NG & NR \\
\hline $0.025 / 2$ & $265 \pm 23^{y}$ & $95 \pm 4^{y}$ & $103 \pm 6^{y}$ & $142 \pm 22^{y}$ & $166 \pm 25$ & $96 \pm 10^{y}$ \\
\hline $0.5 / 2$ & $178 \pm 17^{y}$ & $50 \pm 5$ & $87 \pm 18^{y}$ & $98 \pm 22$ & $79 \pm 11$ & $89 \pm 17$ \\
\hline $1 / 2$ & $102 \pm 6$ & $33 \pm 4$ & $93 \pm 25^{y}$ & $48 \pm 5$ & $26 \pm 3$ & $39 \pm 2$ \\
\hline $0.025 / 6$ & $253 \pm 23^{y}$ & $96 \pm 8$ & $109 \pm 19^{y}$ & $154 \pm 11^{y}$ & $126 \pm 16$ & $81 \pm 3^{y}$ \\
\hline $0.5 / 6$ & $240 \pm 15^{y}$ & $62 \pm 5$ & $133 \pm 5^{y}$ & $181 \pm 27^{y}$ & $60 \pm 17^{y}$ & $70 \pm 8$ \\
\hline $1 / 6$ & $141 \pm 18$ & $43 \pm 8$ & $106 \pm 21$ & $61 \pm 6$ & $35 \pm 11$ & $30 \pm 6$ \\
\hline $0.025 / 12$ & $193 \pm 8^{\mathrm{y}}$ & $52 \pm 6$ & $90 \pm 11^{\mathrm{y}}$ & $125 \pm 17^{y}$ & $51 \pm 7$ & $61 \pm 10$ \\
\hline $0.5 / 12$ & $173 \pm 3$ & $63 \pm 8$ & $135 \pm 39$ & $109 \pm 15$ & $81 \pm 12$ & $70 \pm 7$ \\
\hline $1 / 12$ & $163 \pm 10$ & $29 \pm 3$ & $77 \pm 5$ & $54 \pm 9$ & $42 \pm 2$ & $20 \pm 3$ \\
\hline
\end{tabular}

${ }^{{ }^{2} \mathrm{HY}}=$ 'Bright's Hybrid', LO = 'Lovell', M = 'Myrobalan', MA = 'Marianna', NG = 'Nemaguard', NR = 'Nemared'. Values are untransformed original means $\pm \mathrm{SE}$.

yOnly four to five observations, all others had six observations. 
'Bright's Hybrid' than in those grafted on 'Nemared' under $1 \mathrm{~mm}$ $\mathrm{B}$ and $12 \mathrm{dS} \cdot \mathrm{m}^{-1}$ salt (Fig. 1, bottom). This result indicated that the tolerance of a rootstock to $B$ and salinity can influence the response of the scion.

The effect of salinity and $B$ on the accumulation of $B$ in six Prunus rootstocks. Accumulation of B in root tissue varied greatly and did not show any clear relationship between treatment and tissue concentration (data not shown). However, leaf B concentrations increased with increasing $\mathrm{B}$ in the growth medium in all rootstocks, which is typical in 'Bright's Hybrid' (Fig. 2). Leaf B increased $50 \%$ to $80 \%$ and $100 \%$ to $150 \%$ over the control as B in the medium increased from 0.025 to $0.5 \mathrm{~mm}$ and 0.025 to $1.0 \mathrm{~mm}$, respectively. There was no significant effect of salinity on leaf $\mathrm{B}$

Table 5. Partial $R^{2}$ values from stepwise analysis with stem death as the dependent variable. Combined data of all rootstocks.

\begin{tabular}{lcc}
\hline \hline Variable & $R^{2}$ \\
\hline & Leaf & \\
$\mathrm{B}$ & & 0.0545 \\
$\mathrm{Na}$ & & 0.0039 \\
$\mathrm{SO}_{4}-\mathrm{S}$ & Stem & 0.0171 \\
& & \\
$\mathrm{~B}$ & & $0.4331^{* * *}$ \\
$\mathrm{Na}_{\mathrm{SO}_{4}-\mathrm{S}}$ & 0.0006 \\
\end{tabular}

${ }^{* * * *}$ Significant at $P<0.001$. The forward selection of variables was in the following sequence: stem $\mathrm{B}$, leaf $\mathrm{B}$, stem $\mathrm{SO}_{4}-\mathrm{S}$, and leaf $\mathrm{Na}$. For all other variables, $R^{2}$ was obtained from backward elimination.

Table 6. General linear models procedure analysis of stem $B$ concentration after $\log$ transformation. Stem B concentration was determined 14 months after exposing six Prunus rootstocks to varying B and salinity treatments.

\begin{tabular}{lrcc}
\hline \hline Source & df & Mean square & F value \\
\hline B & 2 & 3.60 & $253^{* *}$ \\
Salinity (S) & 2 & 0.348 & $24.6^{* *}$ \\
Rootstock (R) & 5 & 0.631 & $44.5^{* *}$ \\
$\mathrm{~B} \times \mathrm{S}$ & 4 & 0.0787 & $5.6^{* *}$ \\
$\mathrm{~B} \times \mathrm{R}$ & 10 & 0.0783 & $5.5^{* *}$ \\
$\mathrm{~S} \times \mathrm{R}$ & 10 & 0.0548 & $3.9^{* * *}$ \\
$\mathrm{~B} \times \mathrm{S} \times \mathrm{R}$ & 20 & 0.0658 & $4.6^{* *}$ \\
Error & 159 & 0.0142 & \\
\hline
\end{tabular}

${ }^{\text {*** }}$ Significant at $P<0.01$. concentration on any rootstock (Fig. 2). In all treatments and in all rootstocks except 'Myrobalan', tissue B concentrations were lower in leaves than in stems and did not differ consistently between rootstock and treatment. The much higher accumulation of B in stem than leaf tissue is a characteristic of Prunus rootstocks.

Compared with leaf B, stem B responded much more dramatically to changes in growth medium B, and significant interactions between rootstock, salinity, and B were evident. Stem B concentrations increased $100 \%$ to $300 \%$ and $200 \%$ to $1000 \%$ over the control as B increased from 0.025 to $0.5 \mathrm{~mm}$ and 0.025 to $1.0 \mathrm{~mm}$, respectively (Table 7). Stem B levels in 'Bright's Hybrid' ranged from $48 \mu \mathrm{g} \cdot \mathrm{g}^{-1}$ in the control to $558 \mu \mathrm{g} \cdot \mathrm{g}^{-1}$ at the highest B concentration in the medium. In all rootstocks except 'Nemared', increasing salinity significantly reduced B accumulation in stem tissues (Table 7). This effect was significant in 'Bright's Hybrid', in which adding salt at $12 \mathrm{dS} \cdot \mathrm{m}^{-1}$ to the high $\mathrm{B}$ treatment reduced $\mathrm{B}$ accumulation by $80 \%\left(558 \mathrm{vs} .145 \mu \mathrm{g} \cdot \mathrm{g}^{-1}\right)$. There was a strong negative correlation between $B$ concentration in the stem and salt in the growth medium under high B for 'Bright's Hybrid', 'Myrobalan', and 'Nemaguard' ( $r=-0.888,-0.762,-0.781$, respectively).

Effect of $\mathrm{B}$ and salinity on $\mathrm{Na}$ and $\mathrm{SO}_{4}$ accumulation. Regression analysis indicated that there was no significant correlation between $\mathrm{B}$ application and tissue $\mathrm{Na}$ levels. As such, we will only discuss the effect of salinity on tissue Na concentration at the low $\mathrm{B}$ treatments. Leaves contained the highest $\mathrm{Na}$ concentrations of all tissues, and leaf $\mathrm{Na}$ concentrations varied most significantly (and consistently) between rootstocks and treatments (Fig. 3). With the addition of salt, leaf Na concentrations increased dramatically in all rootstocks except 'Marianna', which had the lowest leaf $\mathrm{Na}$ concentrations. Highest concentrations of $\mathrm{Na}$ occurred in 'Myrobalan' followed by 'Bright's Hybrid', 'Nemared', 'Nemaguard', and 'Lovell'. Although leaf Na concentrations of up to $12000 \mu \mathrm{g} \cdot \mathrm{g}^{-1}$ dry weight $(1.2 \%)$ were recorded in 'Myrobalan', the growth of this rootstock was not significantly affected by high salinity and leaves did not show symptoms of Na toxicity (data not shown).

In contrast to $\mathrm{Na}$, a very significant correlation between $\mathrm{B}$ treatment and tissue $\mathrm{SO}_{4}$ was observed and there were significant differences in $\mathrm{SO}_{4}$ accumulation among rootstocks. Thus, $\mathrm{SO}_{4}$ concentrations in leaves (and stems) decreased markedly in response to increasing B in the growth medium (Fig. 4 top vs. bottom). This correlation was marked in 'Bright's Hybrid', in which, at the highest salt level, leaf $\mathrm{SO}_{4}$ levels were reduced by $80 \%$ with the addition of $1.0 \mathrm{~mm} \mathrm{~B} \mathrm{(Fig.} \mathrm{4).} \mathrm{Significant} \mathrm{B-induced}$

Table 7. Stem B concentrations $\left(\mu \mathrm{g} \cdot \mathrm{g}^{-1} \mathrm{dry}\right.$ weight $)$ of six Prunus rootstocks grown under varying B and salinity treatments. Plants were exposed to treatments for 14 months.

\begin{tabular}{|c|c|c|c|c|c|c|}
\hline \multirow{2}{*}{$\begin{array}{l}\mathrm{B}(\mathrm{mM}) / \\
\text { salt }\left(\mathrm{dS} \cdot \mathrm{m}^{-1}\right)\end{array}$} & \multicolumn{6}{|c|}{ Rootstock $^{z}$} \\
\hline & $\mathrm{HY}$ & $\mathrm{LO}$ & $\mathrm{M}$ & MA & NG & NR \\
\hline $0.025 / 2$ & $48 \pm 16^{y}$ & $76 \pm 18$ & $45 \pm 9$ & $86 \pm 14$ & $62 \pm 9$ & $53 \pm 10$ \\
\hline $0.5 / 2$ & $152 \pm 16$ & $117 \pm 14$ & $69 \pm 5$ & $242 \pm 44$ & $182 \pm 42$ & $269 \pm 75$ \\
\hline $1 / 2$ & $558 \pm 45$ & $415 \pm 115$ & $126 \pm 21$ & $171 \pm 41$ & $312 \pm 46$ & $211 \pm 22$ \\
\hline $0.025 / 6$ & $136 \pm 8^{y}$ & $68 \pm 3$ & $51 \pm 4$ & $54 \pm 6$ & $65 \pm 8$ & $83 \pm 8$ \\
\hline $0.5 / 6$ & $97 \pm 6$ & $157 \pm 18$ & $58 \pm 14$ & $97 \pm 6$ & $200 \pm 12$ & $134 \pm 2$ \\
\hline $1 / 6$ & $234 \pm 7$ & $277 \pm 48$ & $67 \pm 8$ & $127 \pm 14$ & $275 \pm 33$ & $268 \pm 30$ \\
\hline $0.025 / 12$ & $37 \pm 6$ & $90 \pm 6$ & $35 \pm 1$ & $48 \pm 8$ & $70 \pm 8$ & $60 \pm 3$ \\
\hline $0.5 / 12$ & $74 \pm 12$ & $137 \pm 20$ & $43 \pm 7$ & $77 \pm 11$ & $147 \pm 26$ & $91 \pm 3$ \\
\hline $1 / 12$ & $145 \pm 4$ & $253 \pm 66$ & $55 \pm 4$ & $197 \pm 33$ & $138 \pm 39$ & $416 \pm 15$ \\
\hline
\end{tabular}

${ }^{\mathrm{z}} \mathrm{HY}=$ 'Bright's Hybrid', LO = 'Lovell', M = 'Myrobalan', MA = 'Marianna', NG = 'Nemaguard', NR = 'Nemared'. Values are untransformed original means $\pm \mathrm{SE}$.

yDuplicate observations, all others had three. 


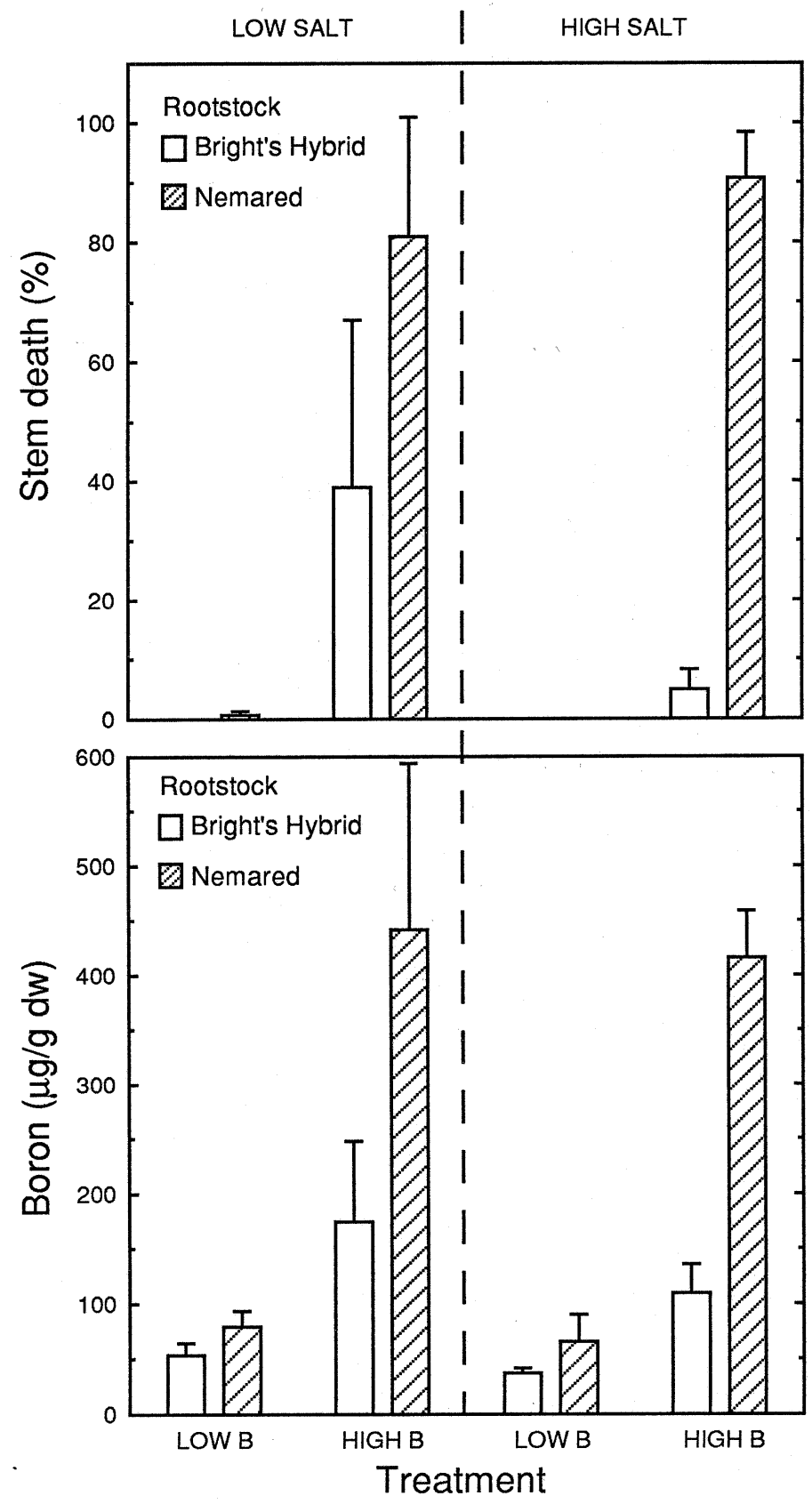

Fig. 1. The effect of rootstock on scion response after 14 months of B and salinity treatments. (Top) Mean percentage stem death. (Bottom) Stem B concentration. 'Titan' almond was the scion in all cases.

depression of leaf $\mathrm{SO}_{4}$ concentrations was also observed in 'Lovell' and 'Nemaguard' rootstocks and probably also in 'Nemared' (Fig. 4). A negative correlation of $r=-0.799,-0.940$, and -0.672 for 'Bright's Hybrid', 'Lovell', and 'Nemaguard', respectively, was observed.

\section{Discussion}

Research on the response of Prunus rootstocks to salinity or B toxicity and their interaction is important because, in many arid regions, high levels of B and salt coexist (Dhankhar and Dahiya, 1980). Results presented here indicate that $B$ and salinity interact to influence the expression of toxicity symptoms, plant growth and survival, and tissue ion concentrations in Prunus.

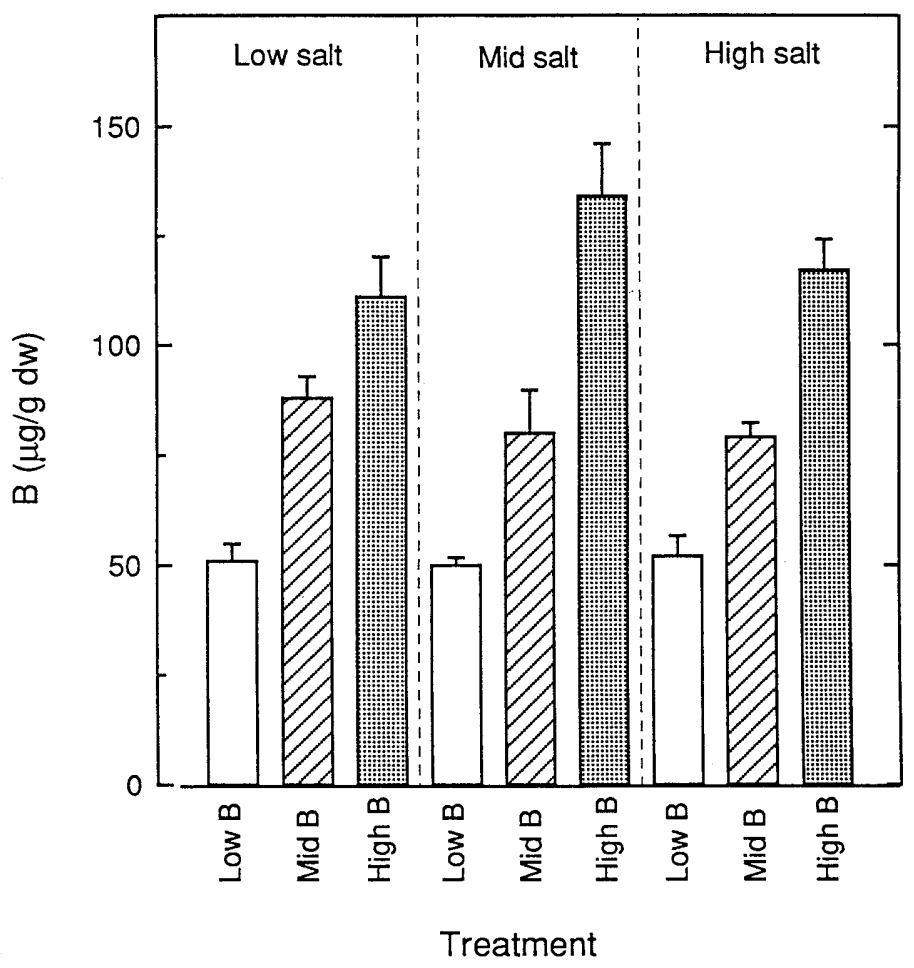

Fig. 2. The effect of 14 months of $B$ and salinity treatments on leaf $B$ concentration in 'Bright's Hybrid'. Boron was supplied at $0.025,0.5$, or $1.0 \mathrm{~mm}$ (low, medium, high) and salinity $\left(3 \mathrm{Na}_{2} \mathrm{SO}_{4}: 1 \mathrm{CaCl}_{2}\right)$ was supplied to the growth medium at conductivity of 2,6 , or $12 \mathrm{dS} \cdot \mathrm{m}^{-1}$ (low, medium, high).

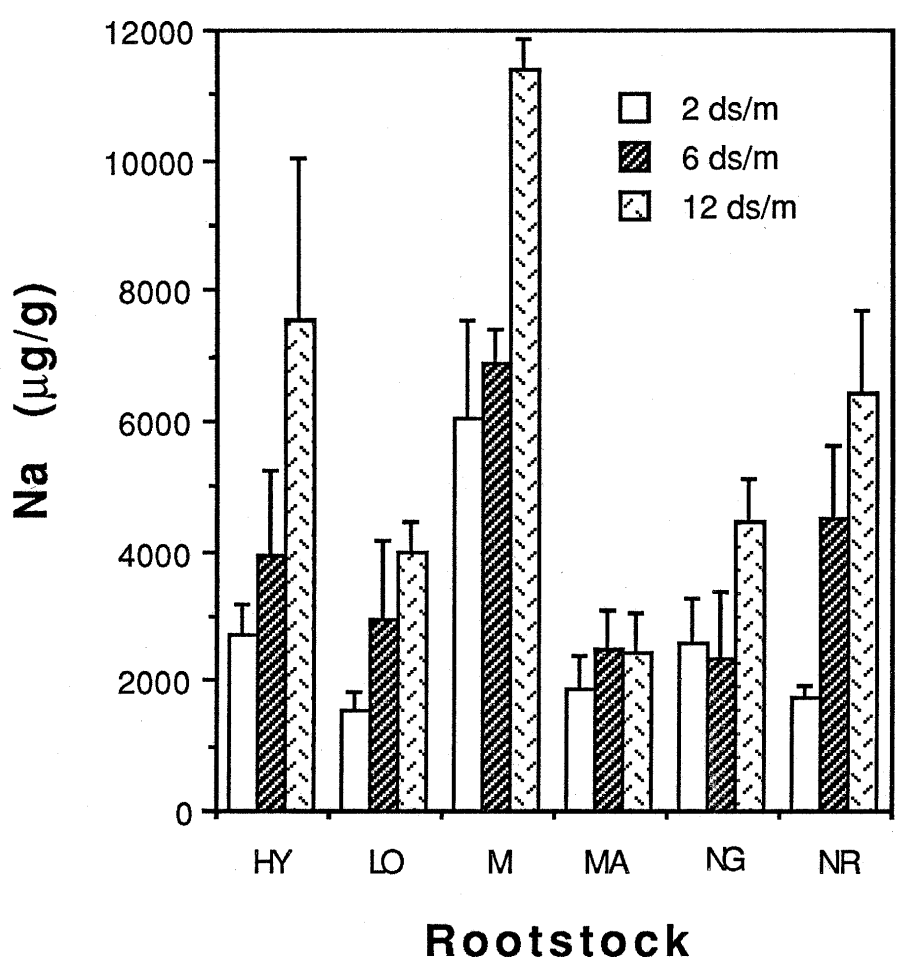

Fig. 3. The effect of 14 months of salinity $\left(3 \mathrm{Na}_{2} \mathrm{SO}_{4}: 1 \mathrm{CaCl}_{2}\right.$, ) treatments on leaf Na concentration of six Prunus species. All plants were exposed to low B $(0.025$ $\mathrm{mm}$ ). $\mathrm{HY}=$ 'Bright's Hybrid', LO = 'Lovell', M= 'Myrobalan', MA = 'Marianna',; $\mathrm{NG}=$ 'Nemaguard', $\mathrm{NR}=$ 'Nemared'.

In Prunus, B toxicity symptoms are correlated with stem B concentrations. Prunus leaves do not exhibit B toxicity symptoms and leaf $\mathrm{B}$ concentrations are not closely correlated with stem 

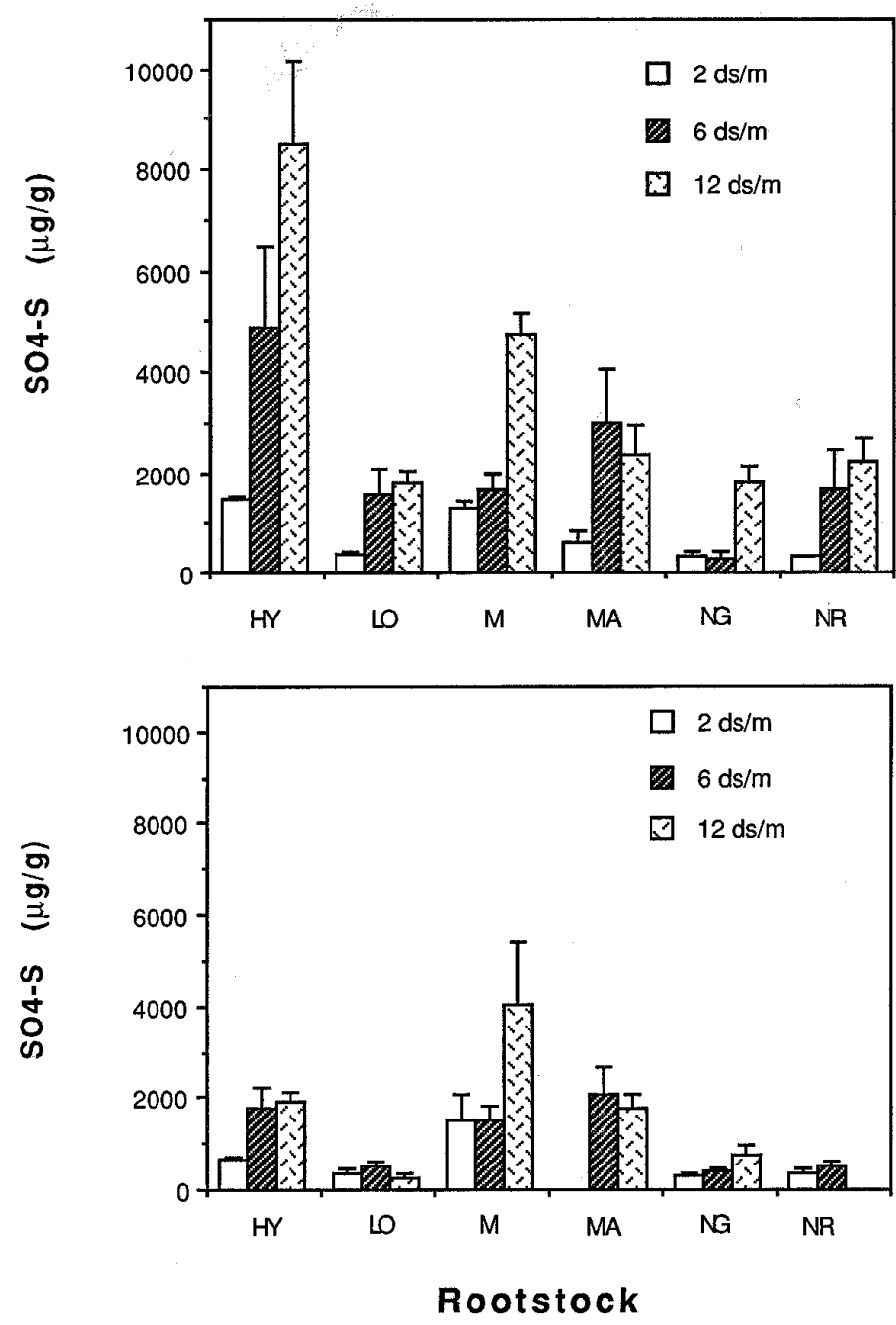

Fig. 4. The effect of 14 months of salinity $\left(3 \mathrm{Na}_{2} \mathrm{SO}_{4}: 1 \mathrm{CaCl}_{2}\right.$,) treatments on leaf $\mathrm{SO}_{4}^{2-}$ concentration of six Prunus species. (Top) All plants were exposed to low B (0.025 mm. (Bottom) All plants were exposed to high B (1.0 mm). HY = 'Bright's Hybrid', LO = 'Lovell', M = 'Myrobalan', MA = 'Marianna', NG = 'Nemaguard', NR = 'Nemared'.

symptoms (Eaton, 1944; Woodbridge, 1955). Hence, for Prunus, the analysis of young stems (and probably also immature fruit) (Brown et al., 1991) is the most sensitive indicator of B toxicity.

Considerable differences exist among rootstocks for B accumulation and the expression of B toxicity in above-ground parts. There was a close relationship between stem B concentrations and the development of toxicity symptoms. Stem B concentrations can be used, therefore, to rank the rootstocks regarding B tolerance. Of the rootstocks tested in this experiment, 'Myrobalan' plum and 'Bright's Hybrid' are the most tolerant rootstocks and 'Marianna' plum and 'Lovell', 'Nemaguard', and 'Nemared' peaches are the most sensitive. Stem death was associated with stem B concentrations $>150 \mu \mathrm{g} \cdot \mathrm{g}^{-1}\left(100 \mu \mathrm{g} \cdot \mathrm{g}^{-1}\right.$ dry weight in 'Marianna'). These results agree with the limited results of Hansen $(1948,1955)$, who reported a similar rootstock ranking. In one experiment, he classified almond (no cultivar specified) and 'Myrobalan' as more tolerant than either apricot (no cultivar specified) or 'Marianna' and 'Shalil' peach (Hansen, 1948), while in a second experiment he observed that almond (no cultivar specified) was more resistant to excess B than 'Lovell' peach (Hansen, 1955).

Results of grafting experiments demonstrate that rootstock can reduce $B$ accumulation in the scion and reduce the impact of high
B. Significantly, the B-tolerant rootstocks ('Bright's Hybrid' and 'Myrobalan') had reduced B concentrations in their shoots and roots. Thus, differential tolerance to B is associated with an ability to limit B uptake by the plant. Recent work by Nable and coworkers (Nable, 1988; Nable et al., 1990; Paull et al., 1992) and earlier work by Brown and Jones (1971) has shown that tolerance to high $\mathrm{B}$ is associated with an exclusion of $\mathrm{B}$ from the plant and not a differential distribution of $\mathrm{B}$ within the plant. Thus, using rootstocks with reduced $\mathrm{B}$ uptake can help maintain tree production in high-B soils.

In the experiments described here, we found no direct correlation between tissue $\mathrm{B}$ and tissue $\mathrm{Na}$ or $\mathrm{Cl}$ and the expression of $\mathrm{B}$ toxicity. Nevertheless, the presence of salt in the growth medium reduced stem tissue $B$ accumulation (and B toxicity) in all rootstocks except 'Nemared'. In addition, there was a strong negative correlation between stem $\mathrm{B}$ and stem $\mathrm{SO}_{4}$ concentrations. There was no correlation between stem $\mathrm{SO}_{4}$ concentrations and plant growth. Thus, saline growth conditions can influence B toxicity in Prunus.

We observed a strong negative correlation between B concentration in the stem and salt concentrations in the growth medium under high B in some rootstocks. As we did not apply differential $\mathrm{SO}_{4}$ (i.e., without $\mathrm{Na}$ ) we cannot conclude that the salinity-induced reduction in $\mathrm{B}$ accumulation was directly due to $\mathrm{SO}_{4}$. Nevertheless, the lack of any clear relationship between $\mathrm{B}$ and tissue $\mathrm{Na}$ or $\mathrm{Cl}$ and the significant negative correlation between tissue $\mathrm{B}$ and tissue $\mathrm{SO}_{4}$ suggests that $\mathrm{SO}_{4}$ could be responsible for the salinity-induced decline in tissue $\mathrm{B}$. The reason for this interaction is unclear, and we are not aware of any previous evidence for this interaction. Leaf $\mathrm{SO}_{4}$ concentrations were strongly reduced by high levels of $\mathrm{B}$ in the growth medium, further suggesting that there is a specific $\mathrm{B} \times \mathrm{SO}_{4}$ interaction in Prunus.

Recently, we have shown that B uptake is a passive process (P.H. Brown and H. Hu, unpublished data) in which the uncharged $\mathrm{H}_{3} \mathrm{BO}_{3}$ molecule ( $\left.\mathrm{kPa} 9.24\right)$ passes freely through the root plasma membrane. In contrast, $\mathrm{SO}_{4}$ is taken up as a divalent anion and must, therefore, involve active uptake (since there is a net negative charge inside the plasma membrane). As a result, direct competition for uptake with the passively assimilated, noncharged B is unlikely. Given the large differences in $\mathrm{B}$ compared to $\mathrm{SO}_{4}$ concentrations in the growth medium, it is also unlikely that B is competitively inhibiting $\mathrm{SO}_{4}$ uptake at the root surface. The mechanism of this $\mathrm{B} \times \mathrm{SO}_{4}$ interaction remains unknown.

Prunus rootstocks differ significantly in their tolerance of salinity and $\mathrm{B}$, and using a tolerant rootstock can restrict $\mathrm{B}$ accumulation in the grafted scion. Prunus also seems to be unique in its expression of B toxicity and the accumulation of B in stems, a result suggesting that stem tissue is the best indicator of $\mathrm{B}$ toxicity. The strong negative correlation between $\mathrm{B}$ and $\mathrm{SO}_{4}$ observed in Prunus cannot be explained by our current understanding of B in plants. It is not known if this interaction is observed in other species. Identifying Prunus rootstocks tolerant of high B and salinity and recognizing the symptoms of B toxicity will help manage almond production in arid and semi-arid regions.

\section{Literature Cited}

Bernstein, L., J.W. Brown, and H.E. Hayward. 1956. The influence of rootstock on growth and salt accumulation in stone-fruit trees and almonds. Proc. Amer. Soc. Hort. Sci. 68:86-95.

Brown, J.C. and W.E. Jones. 1971. Differential transport of B in tomato (Lycopersicon esculentum Mill.) Physiol. Plant. 25: 279-282.

Brown, P.H., D.E. Rolston, J.W. Biggar, H.I. Nightingale, and R.B. Hutmacher. 1991-92. Assimilation of B in almond trees and seedling rootstocks in relation to trickle irrigation, soil B and saline well water 
containing boron. Annu. Tech. Prog. Rpt., Univ. of California Salinity/ Drainage Program Annu. Rpt., Div. Agr. Natural Resources.

Catlin, P. B., G.J. Hoffman, R.M. Mead, and R.S. Johnson. 1993. Longterm response of mature plum trees to salinity. Irr. Sci. 13:171-176.

Croughan, T.P. and D.W. Rains. 1982. Terrestrial halophytes: Habitats, uses and productivity, p. 245-255. In: A. Mitsui and C.C. Black (eds.). Handbook of biosolar resources. part 2. Basic principles. CRC Press, Boca Raton, Fla.

Dhankhar, D.P. and S.S. Dahiya. 1980. The effect of different levels of boron and soil salinity on the yield of dry matter and its mineral composition in Ber (Zizyphus rotundifolia). Intl. Symp. Salt Affected Soils. Karnal. p. 396-403.

Eaton, F.M. 1944. Deficiency, toxicity, and accumulation of boron in plants. J. Agr. Res. 69:237-274

Fernandez, G.C.J. 1992. Residual analysis and data transformations: important tools in statistical analysis. HortScience 27:297-300.

Gomez, K.A. and A.A. Gomez. 1984. Statistical procedures for agricultural research. 2nd ed. Wiley, New York. p. 272-356.

Greenway, H. and R. Munns. 1980. Mechanism of salt tolerance in nonhalophytes. Annu. Rev. Plant Physiol. 31:141-190

Hayward, H.E. and E.M. Long. 1946. Vegetative responses of the Elberta peach on Lovell Shalil rootstocks to high chloride and sulfate solution. U.S. Dept. of Agr. Tech. Bul. 922.

Hansen, C.J. 1948. Influence of the rootstock on injury from excess boron in French (Agen) prune and President plum. Proc. Amer. Soc. Hort. Sci. 51:239-244.

Hansen, C.J. 1955. Influence of the rootstock on injury from excess boron in Nonpareil almond and Elberta peach. Proc. Amer. Soc. Hort. Sci. 65:128-132.
Hoagland, D.R. and D.J. Arnon. 1950. The water-culture method for growing plants without soil. Circ. Calif. Agr. Expt. Sta. 347.

Hoffman, G.J., P.B. Catlin, R.M. Mead, R.S. Johnson, L.E. Francois, and D. Goldhammer. 1988. Yield and foliar injury responses of mature plum trees to salinity. Irr. Sci. 10:215-229.

Littlefield, E.S., R.O. Miller, and R.M. Carlson. 1990. Determination of sulfate-sulfur in plant tissue by inductively coupled plasma spectrometry. Commun. Soil Sci. Plant Anal. 21:1577-1586.

Mass, E.V. 1986. Salt tolerance of plants. Applied Agr. Res. 1:12-26.

Nable, R.O. 1988. Resistance to boron toxicity amongst several barley and wheat cultivars: A preliminary examination of the resistance mechanism. Plant and Soil 112:45-52.

Nable, R.O., B. Cartwright, and R.C.M. Lance. 1990. Genotypic differences in boron accumulation in barley: Relative susceptibilities to boron deficiency and toxicity, p. 243-251. In: N. El-Bassam, M. Dambroth, and B.C. Loughman (eds.). Genetic aspects of plant mineral nutrition. Kluwer, London.

Nicholaichuk, W., A.J. Leyshon, Y.W. Jame, and C.A. Campbell. 1988. Boron and salinity survey of irrigation projects and boron adsorption characteristics of some Saskatchewan soils. Can. J. Soil. Sci. 68:77-90.

Paull, J.G., R.O. Nable, A.W.H. Lake, M.A. Materne, and A.J. Rathjen. 1992. Response of annual medics (Medicago spp.) and field peas (Pisum sativum) to high concentrations of boron. Genetic variation and the mechanism of tolerance. Austral. J. Agr. Res. 43:203-213.

SAS Institute. 1982. SAS user's guide: Statistics. SAS Inst., Cary, N.C. p. 39-83, 101-110, 139-200.

Woodbridge, C.G. 1955. The boron requirements of stone fruit trees. Can. J. Agr. Sci. 35:282-286. 